\title{
Marilet Sienaert
}

\section{'n Aspek van intertekstualiteit in die poësie van Breytenbach: François Villon en die Middeleeuse Franse literêre tradisie.}

\begin{abstract}
Apart from biographical correlations marking the poetry of Breyten Breytenbach and François Villon (imprisonment and exile) there is an ongoing intertextual dialogue between the two authors on which this article focusses. Thematic correlations indicate that both oeuvres link up with the age-old literary tradition of the ubi sunt and the danse macabre. Stylistic correlations, such as word-play, the polyvalent nature of the text and the use of paradox as creative principle appear to be symptomatic of the existential insecurity characterizing historically and culturally transitional periods. This implies inter alia that the parallel between the two oeuvres is not merely anecdotal, but that the Breytenbach discourse has validity in a context far broader than South Africa and ties in with a universal literary tradition where master data of the text unfold in a wholly different dimension than a first level meaning might suggest.
\end{abstract}

\section{Inleidend}

Dit is algemeen bekend dat die Breytenbach-oeuvre raakpunte toon met die werk van baie ander skrywers, soos dié van Borges, Villon, Baudelaire, Rimbaud en Michaux, om net enkele name te noem. Dit gaan hier in die eerste plek nie om beïnvloeding nie, maar eerder om 'n intertekstuele gesprek wat in hierdie artikel toegelig word aan die hand van die opvallende parallel tussen die werk van Breytenbach en die Middeleeuse Franse digter, François Villon (1431-1463). Villon se vernaamste werk is twee lang poëtiese geskrifte, onderskeidelik getiteld Le Lais (320 versreëls) en Le Testament (2023 versreëls), wat verskeie ballades en rondele insluit. Sy invloed op die 
Europese letterkunde van die vyftiende eeu (die oorgangsfase van die Middeleeue na die Renaissance) word baie hoog geskat, en hy word in meer as een opsig beskou as 'n voorloper van die moderne Franse letterkunde. Myns insiens is die intertekstuele gesprek tussen die werk van Breytenbach en Villon nie bloot anekdoties nie, maar plaas dit die poësie van Breytenbach binne 'n baie groter konteks as net die aktuele Suid-Afrika van hier en nou, en werp dit moontlik ook lig op die aard van betrokke poësie oor die algemeen.

As vertrekpunt word geneem die feit dat die werk van beide digters getuig van sterk maatskaplike betrokkenheid en sosiale bewussyn. Wanneer Villon se Testament beskou word as die modele d'une poésie engagée (Michel, 1972:11) is dit 'n stelling wat eweneens van toepassing sou kon wees op 'n groot deel van die Breytenbach-oeuvre. 'n Voor-die-hand-liggende verdere raakpunt is dat albei digters ballingskap en gevangenskap moes verduur wat as voedingsbron vir hul poësie gedien het. Aangesien die omstandighede wat gelei het tot Breytenbach se inhegtenisneming algemeen bekend is, word hier volstaan met 'n kort biografiese oorsig van Villon.

In 1452 gradueer Villon aan die Sorbonne en as student is hy dikwels in straatgevegte betrokke. By een so 'n geleentheid verwond hy 'n priester noodlottig, en moet hy homself versteek vir die gereg. In 1456, op Ou Kersaand, ruk 'n gekskeerdery met vriende hand-uit en is Villon betrokke by die diefstal van 500 goue krone uit die Collège de Navarre. Om arrestasie vry te spring, verlaat hy Parys en gaan bly op die platteland. Van 1457 tot 1460 word hy aangehou in die gevangenis van Orléans, en weer in 1461 in Meung-sur-Loire. Dit is onseker wat sy oortredings was, maar hy, sowel as 'n paar ander gevangenes, is aan die einde van dieselfde jaar deur Lodewyk XI begenadig en vrygelaat by geleentheid van die koning se besoek aan dié landstreek. Terug in Parys word hy in 1462 vir diefstal aangehou in die berugte Châtelet, maar word gou weer vrygelaat. In dieselfde jaar is hy egter weer betrokke by 'n argument waar 'n kerklike notaris doodgesteek word, en op grond van Villon se omstrede verlede word hy hierdie keer ter dood veroordeel. Hy teken egter met sukses appèl aan teen hierdie vonnis en word vir 10 jaar uit Parys verban. Hoe hy eindelik dood is, is nie bekend nie, maar ná 1463 (toe hy dus 31 jaar oud was) is niks meer van hom gehoor nie.

Historici beklemtoon herhaaldelik dat die besonderhede omtrent Villon se oortredings vaag is, en dat Parys gedurende daardie tyd (dit was net ná afloop van die Honderdjarige oorlog, 1337-1453) in elk geval chaoties was. In die geskiedenis word Villon onthou as iemand wat straf moes verduur, soos deur die stelsel bepaal, (Charpier,1958:51) en nie as blote skurk of moordenaar nie, hoewel sy assosiasie met die kriminele "broederskap" van die sogenaamde Coquillards nie oorgesien kan word nie. Moderne kritici lễ verder baie min of geen klem meer op Villon as argetipe van die poète maudit nie (Le Gentil,1967:147), en die raakpunt met Breytenbach is ook nie te vinde in die legendariese figuur wat Uys Krige $(1950: 60-70)$ in die vyftigerjare van Villon 
skets nie. Meer as enige iets anders word hy onthou as 'n révolté, 'n opstandeling teen die sosiale strukture van sy tyd maar veral ook teen die ongelykheid van lotsbestemmings of die condition humaine. Hoewel persoonlike ooreenkomste tussen Villon en Breytenbach in hierdie verband miskien interessant is, word dit hier net genoem, aangesien die parallel wat in hierdie artikel belig word op die vlak van die teks self lê.

\section{Tekstuele parallelle ${ }^{1}$}

Reeds in Breytenbach se vroegste digbundels word spore van die Villonoeuvre aangetref, 'n verskynsel wat toeneem in die bundels wat ná sy vrylating gepubliseer is. 'n Paar voorbeelde uit die vroeë bundels kan vermeld word. In "Slaap onder lede" (Breytenbach,1981a:122) word Villon se "Ballade des dames du temps jadis", soos deur Krige (1950:22) in Afrikaans vertaal, direk aangehaal:

maar van wonder gaan die son onder

en waar is die sneeu van voorverlede jaar

waar is die eiers bloed in die sneeu.

Die titel "Testament van 'n rebel" (Die huis van die dowe, 1967:95) roep onmiddellik die Fransman se Testament op, maar dit is veral op die terrein van beelding waar die analogie met Villon se woordkuns opval. Vergelyk byvoorbeeld Villon se terdoodveroordeeldes wat aan die galg rondswaai in "Ballade des pendus":

La pluye nous a debuez et lavez,

Et le soleil dessechiez et noircis;

Pies, corbeaulx, nous ont les yeux cavez,

Et arrachié la barbe et les sourcis.

Jamais nul temps nous ne sommes assis;

Puis ça, puis la, comme le vent varie,

A son plaisir sans cesser nous charie,

Plus becquetez d'oiseaulx que dez a couldre.

(The rain has washed and scrubbed us day by day;

The sun has dried and blackened us piteously.

Magpies and crows have pecked our eyes away,

Torn out our beards and eyebrows painfully.

We cannot sit, but swing perpetually,

As the wind varies, blown from side to side.

At the wind's pleasure, constantly we ride,

Pricked by birds' beaks, like a tailor's fingerstall)

1. Die aanhalings uit die Villon-teks wat gebruik word, is die uit die manuskrip wat deur Michel (1972) geredigeer is, en die Engelse vertaling van Beram Saklatvala (1968) word deurgaans gebruik. Die Nederlandse vertaling deur Van Altena (1965) wat geraadpleeg is, was dikwels onbevredigend en verarmend en word dus glad nie hier gebruik nie. Tensy anders vermeld, is alle kursivering van aanhalings uit die Villon- sowel as Breytenbachtekste my eie. 
en Breytenbach (1981b:41) se "my treurbleek viool my liefdesinstrument" in Lotus (1981b:41):

en sien jou reeds hang

die gebeente van 'n droom

so sonder snare

dat net die slaplippige wind

nog klagtes kan suig

uit jou verskole maar reeds droë holtes

en ook "(woordverdryf)" in Lotus (1981b:149):

my duif, môre sal jy aan die tou

kan kom pik

môre sal my lyf

in jou ontbind...

Verskeie kritici, onder meer Dufournet (1980:14), beklemtoon die verwantskap tussen die poësie van Villon en die skilderkuns van Jeronimus Bosch (1450:1516), 'n analogie wat ook met die werk van Breytenbach gemaak word: "Zijn poëzie is een verslag van dood, ellende en aftakeling, net als de schilderijen van Jeroen Bosch ... waardoor Breytens schilderkunst en poëzie sterk is beïnvloed" (Van Dis,1974:41). Vergelyk in hierdie verband "Bevolkte dood" uit Kouevuur (1981a:107) wat Breytenbach opdra aan Bosch, en wat hy afsluit met:

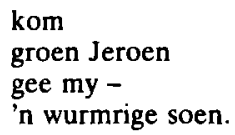

Hierdie byna lukrake raakpunte met die werk van Villon berei egter die weg vir meer pertinente analogieë in die latere bundels wat Breytenbach tydens sy gevangenskap geskryf het: analogieë wat dui op 'n heel doelbewuste intertekstuele gesprek. In Buffalo Bill (1984:37) is daar byvoorbeeld 'n ballade (Villon se geliefkoosde digvorm) direk opgedra aan "Fransman Viljoen", en is die beskrywing van 'n kadawer wat in die wind aan die galg rondswaai en wat deur die kraaie kaal gepik word, weer eens soos 'n eggo van die reeds aangehaalde "Ballade des pendus".

"La neige d'antan" in Lewendood, (1985:77) het as titel 'n gedeelte van die bekende refrein uit Villon se "Ballade des dames du temps jadis", 'n frase wat in albei tekste sinspeel op verganklikheid en vervloë tye, soos beklemtoon deur die refreinagtige herhaling van die woorde "onthou julle nog" in die Breytenbach-teks.

Opvallend ook is die gevalle waar Breytenbach die Middeleeuse digter direk aanspreek of waar hy by name na hom verwys:

dit was 'n skare van bekende gesigte

byna onsigbaar, met vroeë sterre se sit bo sy hoof op 'n rydier 
Federico - sy borshemp en das vol ink en bloed

Françooi voëldroog aan 'n galg. Osip met sy derms in albei hande gebak.

(Voetskrif, 1976:25)

Die gedig “(vir Frans Viljoen)" in Lewendood (1985:92-93), suggereer deur middel van die verafrikaanste vorm van Villon se naam 'n intieme of broederlike verhouding; 'n soort geneentheid met die Franse digter. Boonop sluit dit tematies sterk aan by Villon se "Ballade des pendus", aangesien dit in beide gevalle gaan oor terdoodveroordeeldes, en dieselfde hartseer stemming van deernis beide gedigte kenmerk:

mooi loop genote in die lig van die liggaam!

mooi loop met die merke van die nooit-vergeet

na die laaste gevangenis van nooit-onthou -

hamba kahle!

Tematiese sowel as stilistiese ooreenkomste in die Breytenbach - en Villonoeuvres word vervolgens kortliks belig. (Daar word egter nie hier aanspraak gemaak op 'n volledige ondersoek nie, en slegs 'n paar voorbeelde word telkens gegee.)

\section{Tematiese ooreenkomste}

Benewens Villon se sterk liriese liefdesverse en Breytenbach se liefdespoësie wat hier net genoem word, kan gewys word op beide digters se obsessie met die dood, 'n besetenheid wat die poësie van Villon en Breytenbach laat inskakel by die eeue-oue literêre tradisie van die danse macabre of die dodedans soos Villon dit geken het. Verder is dit opvallend dat die doodsmotief by albei digters dikwels manifesteer by wyse van die sogenaamde $u b i$ sunt-tema, wat klem lê op fisiese aftakeling oor die algemeen en op die afsterwe van geliefdes en bekendes.

\subsection{Die ubi sunt-tema}

Literêr-histories gesproke het die ubi sunt-tema sy oorsprong in Bybelse tye, soos in Prediker 1:1-11 waar Salomo met die woorde "alles is tevergeefs" wys op die verganklikheid van alle dinge. In die Middeleeue word hierdie Bybelse tradisie voortgesit, eerstens deur die geskrifte van die kerklike vaders, en daarna deur volksdigters wat in volkslatyn gedig het (Gilson,1932:31-38). Die ubi sunt-tema word deur hierdie digters uitgebrei deur verganklikheid te suggereer aan die hand van die enumerasie van beroemde mense uit die verlede, en deur klem te lê op die verbygaande aard van vroulike skoonheid, soos byvoorbeeld in "Parement et triomphes des dames" deur Oliver de la Marche (1426-1502):

Quest devenue (= wat het geword van) lemperiere de Rome

Dame Eliener fille de Portugal

Quest devenue ma dame la Dauphine 
Quest devenue ma dame de Callabre

Quest devenue de Ravastin la dame ...

Die digter gaan vir vier strofes lank so voort. Spesifiek binne hierdie tradisie lê Villon se "Ballade en vieil langage François", (uit Le Testament, vv.385412), die reeds genoemde "Ballade des dames du temps jadis", (uit Le Testament, vv.329-356) en "Ballade des seigneurs du temps jadis" (uit Le Testament, vv.357-384). Ter illustrasie volg hier 'n aanhaling uit laasgenoemde:

Qui plus, ou est le tiers Calixte,

Dernier decedé de ce nom,

Qui quatre ans tint le papaliste?

Alphonce le roy d'Arragon,

Le gracieux duc de Bourbon,

Et Artus le duc de Bretaigne,

Et Charles Septiesme le bon?

Mais ou est le preux Charlemaigne?

(Calixtus the Third, now where is he,

The last to adopt that name as his own?

Four years he held the Papacy.

Where's Alfonso, King of Aragon?

Where's the great Duke of Bourbon gone?

Arthur in Brittany once did reign,

And Charles the Good - their word is done!

But where is the mighty Charlemagne?)

Breytenbach se "(Mikpunt - 'n Canto vir E.P.)" in Voetskrif, (1976:19-26) en sy "Ballade van ontroue bemindes" in (" $Y K$ "), (1983:112-113) waar verdwene beroemdes of bekendes opgenoem word, sluit direk hierby aan. Laasgenoemde gedig is by die eerste oogopslag 'n parodie van Villon se "Ballade des dames du temps jadis", maar vertoon ten spyte van die spottende ondertoon 'n eie erns en moet dus eerder as 'n pastiche beskou word. (Pastiche, in teenstelling met die parodie wat as 'n "belaglik makende nabootsing" [HAT] omskryf word, impliseer bloot dat een kunswerk dien as model vir 'n ander.) Die ubi sunt-stemming oorheers die gedig - medelye met gestorwenes of verdwenes met klem op die onkeerbaarheid van tyd wat verbygaan, sterk verbeeld met die beskrywing van vallende water in die openingsvers:

"Die water val, die jare gly";

('n eggo van Villon se "dessus riviere ou sur estan" v.334)

"ek sit by Dirk en word beskonker

Hy bied ou vodde nuus vir my"

(werklike "ou nuus", soos wat die ubi sunt-tema 'n stokoue tradisie in die letterkunde is, en die digter dus by voorbaat weet dat sy "wat-het-geword-van"-vrae retories is).

"Wat het geword van I. Jonker?"

"Hy't knaend mos na haar gevry...

Nog 'n skop?"

"Ta, gooi maar wit". 
"Dit was die sêdste begrawery ..."

Wat het geword van jong Ingrid?"

(Kursivering in hierdie aanhaling is die digter s'n.)

Dit gaan hier om die verdwyning van ou vriende soos Ingrid Jonker en Peter Blum, 'n feit waarin Breytenbach sy eie verganklikheid, maar ook sy tydelike verdwyning van die toneel as gevolg van gevangenskap, weerspieël sien: "Wat het geword van Bullebach?"

Breytenbach beklemtoon verder sy isolasie deur middel van kontraswerking wanneer hy spesifiseer dat hierdie ballade "'n Wintervers vir een stem" is, wat onmiddellik by wyse van 'n teenstelling die Villon-teks waarvan dit die pastiche is, oproep, en waar 'n hele koor van stemme ter sprake is. Vergelyk in hierdie verband die studie van Hutcheon (1981:154) wat daarop wys dat 'n parodie (of pastiche) as intertekstuele eggo van die oorspronklike teks spesifiek optree met die doel om die verskil tussen die twee tekste (en nie die ooreenkoms nie), uit te lig.

Echo parlant quant bruyt on maine'

(v.333)

(Where's Echo speaking clear and plain?);

Qui commanda que Buridan

Fust geté en ung sac en Saine?

(vv.341-343)

(And where's the queen who once did reign,

And ordered the scholar Buridan

To be thrown, in a sack in the River Seine?);

La royne Blanche comme lis

Qui chantoit a voix de seraine?

(vv.345-346)

(Queen Blanche, as white as a lily is,

Who sang so sweetly a siren strain -)

Prince, n'enquerez de sepmaine'

(v.353)

(Prince, do not ask this week again)

Nog steeds in verband met "Ballade van ontroue bemindes" is dit opvallend dat Breytenbach hier afwyk van die vrye versvorm wat hy gewoonlik gebruik, en deur middel van die balladevorm doelbewus aansluit by Villon. Verder versterk hy die ubi sunt-gedagte by wyse van herhaling, deur telkens die refrein 'n variasie te maak van die vierde versreël in elke storfe:

"Wat het geword van Ingrid Jonker?"

"Wat het geword van jong Ingrid?"

Wat het geword van Pieter Blum?"

Wat het geword van P. Verbloem?"

"Wat het geword van Breytenbach?"

Wat het geword van Bullebach?"

(Breytenbach se kursivering.) 
Winter, as konvensionele simbool van afsterwe, word deur albei digters aangewend om die ubi sunt-motief uit te bou. Die subtitel van "Ballade van ontroue bemindes", naamlik "'n Wintervers vir een stem", en die begin van die tweede strofe "Die wêreld is koud en verslete daarbo", herinner aan Villon se teks met die suggestie van winterkoue in die woord neiges (sneeu). Die assosiasie van witheid met sneeu (selfs suiwerheid vergaan!) word in die Villon-teks versterk met "La royne Blanche comme lis" (vv.345) wat weer in Breytenbach se gedig 'n weerklank vind in die wit wyn wat gedrink word en in vers 6 van die envoi met "kyk waar lê $\mathrm{I}$. witgraat in die donker". Hierdie laaste reël stel dan ook eksplisief die verband wat tradisioneel bestaan tussen die ubi sunt-tema en die dood, soos elders ook aangevoer deur Breytenbach: "en so draai die wiel voort / verrotting bring aftakeling wat lei na verrotting ..." "(mikpunt - 'n canto vir E.P.)" in Voetskrif (1976:23).

Om verganklikheid aan die hand van die aftakeling van vroulike skoonheid te illustreer, verteenwoordig 'n wegbreek van die kerklike $u b i$ sunt-tradisie, en is van heidense oorsprong (Friedman,1957:499-505). Hierdie soort uitgebreide beskrywing van fisiese verval en die sterk gevoel van verlies wat daarmee gepaardgaan, is deel van 'n baie ou literêre konvensie en word byvoorbeeld reeds aangetref in die Silvae van die Latynse digter Publius Papinius Statius (49-96) waar daar na aanleiding van 'n skedel gevra word: "Waar is die hare waarvan so baie gehou is? / Waar is die neus wat so veel parfuum kon geniet? / Waar is die tong waarmee leuens aan ander vertel is? / Dit is alles deur die wurms verteer ..." / (My eie vertaling van 'n aanhaling in G. Schnurer (1933-35:348).)

Dit is verstaanbaar dat so ' $n$ benadering aanleiding sou gee tot die evokering van die liggaamlike en die erotiese, en dat 'n klemverskuiwing van die verhewe na die gewone of die aardse hier sou plaasvind. Sedert die vyftiende eeu, en veral met Villon wat die ubi sunt-tradisie uitbrei aan die hand van allerlei alledaagshede soos die lot van verliefdes en prostitute, en wat ook nie huiwer om van humoristiese obseniteite in sy toepassing hiervan gebruik te maak nie (bv. in Le Testament vv.517-524) verskuif die klem van die kerklike na die profane:

C'est d'umaine beaulté l'issue!

Les bras cours et les mains contraintes,

les espaulles toutes bossues;

Mamelles, quoy? Toutes retraites;

Telles les hanches que les tetes;

Du sadinet, fy! quant des cuisses

Cuisses ne sont plus, mais cuissetes

Grivelees comme saulcisses.

(This is all human beauty's end -

Arms growing short, and hands constricting;

The shoulders crooked grow, and bend,

The nipples retreat and are shrivelling;

Like the breasts, the haunches are slackening; 
The garden's foul! The thighs? Why these

Are no longer thighs, but are withering,

Speckled and blotched like sausages!)

Nog 'n soortgelyke voorbeeld by Villon is in "Ballade de la belle Heaulmière aux filles de joie" waarin 'n afgeleefde prostituut haar vergange skoonheid betreur.

As voortsetting van hierdie tradisie skryf Breytenbach in (" $Y K$ ") na aanleiding van 'n foto van Jan Rabie:

sien toe vandag jou tronie gebeeldbalk in die koerant; die droom agter die oogholtes lyk nog braaf gesond, die sprekende Janniebaardjie spits (of spiets) kontant, maar ai

hoessit dan ook al spierwit taai en kóúd om die mond?

“('n Gatha vir J.R.)" in (“YK”),1983:100.)

Beide digters pas die ubi sunt-tema ook op 'n introspektiewe manier toe:

Qu 'est ce que j'oy? - Ce suis je! - Qui - Ron cuer,

Qui ne tient mais qu 'a ung petit filet:

Force $\mathbf{n}$ 'ay plus, substance ne liqueur,

Quant je te voy retraict ainsi seulet,

Com povre chien tapy en reculet. -

(Who's there? It's I! Who? Why, your heart is here,

By a small thread suspended tenuously.

I've no more strength: blood, substance, disappear,

When you withdrawn and lonely do I see,

like some poor dog that crouches solitary.)

(Villon in "Debat du cuer et du corpse de Villon");

en:

Nou - na hoe baie maande van eensame opsluiting? -

Kry ek eenklaps 'n regte spieël in my sel, 'n ware oog

van water; maar onder die bevrore oppervlakte

woon 'n lokvoël: 'n verrimpelde verbleikte aap

waarskynlik uit Sjina wat buitensporige gebare beduie

wanneer hy my oog vang.

(Breytenbach se gedig "(Vriespunt)" uit die bundel Lewendood (1985:147), waar hy die ubi sunt-tema spesifiek binne die tronkgegewe op homself toepas.)

Die dood word deur Villon sowel as Breytenbach gesien as 'n onafwendbare natuurgegewe; as deel van 'n onveranderlike natuurlike proses. So byvoorbeeld die refrein van beide "Ballade des dames du temps jadis" en "Ballade en vieil langage françois", waar die (retoriese) ubi sunt-vraag tartend "beantwoord" word met die natuurbeelde van sneeu en wind, albei simbolies van verganklikheid: "Mais où sont les neiges d'antan?" en "Autant en emporte ly vens". Eweneens sluit Breytenbach se gedig "Vir die sangers" wat handel oor terdoodveroordeeldes wat die nag vóor hul teregstelling met gesang deurbring, met die refreinagtige herhaling van die woorde "oral is die 
mens stof en sterfte / en sy klagtes nietigheid" hierby aan (uit Voetskrif (1976:29-31)). Hierdie gedig bring egter vernuwing waarvan daar in die Middeleeuse tradisie geen sprake is nie. Die klem wat deur die ubi suntmotief op die dood gelê word, word nou besweer:

oral is die mens stof en sterfte

en net in ander mense leef hy voort.

en ook:

die hart, die hart is ' $\mathrm{n}$ tydelike vertoef

maar in die sang is die oneindigheid

van die sterwende -

Breytenbach stel hiermee eksplisiet wat net implisiet by Villon te bespeur is. Volgens die Middeleeuse tradisie bepaal die kerklike dogma dat redding alleen van God af kom, en dus grotendeels buite die mens lê, soos wat dit byvoorbeeld vergestalt word in Villon se "Ballade des pendus" waar die envoi 'n direkte versoek aan God is om die terdoodveroordeeldes te vergewe.

In teenstelling hiermee is die verlossingsmotief in "Vir die sangers" verinnerlik en kom redding of beswering van die dood paradoksaal voort uit die veroordeeldes self:

\footnotetext{
Vir julle wat uit die donkerte sing:

vir julle laaste dagbreek - dit word geneem, geëet -

laat julle lied soos heuning wees

verstrengel met dié van die voël,

en ek sal die soetigheid onthou

so lank soos my tong nog bewe, nog hang

in die mond van die bittermooi lewe self
}

(Halleluja ...)

Die tweede reël van hierdie versparagraaf is ' $n$ toespeling op die brood en wyn wat met die laaste Avondmaal gebruik is. "Die sang" (= "dit") speel hier in op die laaste Avondmaal van Christus, die breek van "dagbreek" skep alreeds die assosiasie met brood wat geneem word, gebreek word, geëet word, as deel van die ritueel van offerande van die Lam van God. Verlossing lê by wyse van assosiasie in hierdie gedig dus in die sang self, (vergelyk: "maar in die sang is die oneindigheid / van die sterwende" en die "Halleluja" waarmee die gedig sluit) en lê redding of versoening dus binne die handeling van die veroordeeldes self.

Ook Villon suggereer dat die dood deur die woord besweer kan word deur sy werk Le Testament en Le Lais te noem. Albei hierdie titels beteken nalantenskap en impliseer dus dat, hoewel die dood onafwendbaar is, die digter deur middel van sy woordkuns 'n mate van onsterflikheid bereik. Dit is natuurlik wáár van alle poësie, maar tref veral by Breytenbach waar die tronkbundels juis op terapeutiese wyse lewegewend vir die digter is ("dus herskrywe ek 'n ek al na gelang" ... in "Nekra" (" $Y K$ "), 1983:44). Net soos 
wat die veroordeeldes in hul sang bly voortleef, net so word die poësie 'n proses van transubstansiasie waardeur 'n oomblik van onsterflikheid ervaar mag word. Vergelyk in hierdie verband die Rooms-Katoliek wat met die Nagmaal die getransubstansieerde bloed en vlees van Christus in wyn en brood gebruik, om te mag deel hê aan die ewige lewe. Hierdie proses word psigo-analities ontleed deur C.G. Jung, "Le symbole de la transubstantiation dans la messe" in Les racines de la conscience (1971:207-298).

\subsection{Dodedans-tema}

Tradisioneel verwys die term dodedans na 'n optog of dans waaraan die lewendes en reeds gestorwenes saam deelneem, en as allegorie is dit bedoel om te wys op die onafwendbaarheid van die dood, sowel as die feit dat almal deur die dood gelykgestel word. 'n Voorstelling van die dodedans word so vroeg as 1393 in Frankryk as misteriespel opgevoer om 'n preek oor die sondeval toe te lig (Martineau-Génieys,1978:93-94), maar sedert die vyftiende eeu word die dodedans nie meer met die religieuse geassosieer nie. As motief in die beeldende kunste (vergelyk in hierdie verband Holbein se houtsneewerk en die gravures van Dürer) vier dit hoogty in die laat Middeleeue, en as morbiede en pessimistiese tema in die letterkunde bereik dit 'n hoogtepunt in Villon se leeftyd, wat miskien verklaar kan word aan die hand van die voortdurende oorloë en siekte-epidemies wat aan die orde van die dag was. Soos blyk uit talle kunswerke van dié tyd word die dood gepersonifieer as 'n laggende, dansende skelet wat die mens onverwags en met geweld uit die lewe kom wegruk (Martineau-Génieys,1978:90-91). Deur die uitbeelding van ' $n$ kadawer in verskillende stadia van ontbinding word verganklikheid beklemtoon en die bestaan van 'n hiernamaals in twyfel getrek, 'n verskynsel wat simptomaties van die laat Middeleeue was. In plaas van die engel van God wat die sterwende na 'n ander dimensie weglei, word die klem nou geplaas op 'n soort metamorfose na die niet (Roy,1979:133134).

By Villon word die dodedans treffend vergestalt deur byvoorbeeld die kadawers van terdoodveroordeeldes wat aan hul gesamentlike galg bly rondswaai totdat hulle geheel en al deur die weer en die voëls gestroop is "(Ballade des pendus") en wat dus sodoende 'n makabere dodedans suggereer. Villon het dié ballade geskryf in die tyd toe hy self ter dood veroordeel is, en hy in die dodesel gesit het. Die gedig is 'n roerende versoek aan sy medemens om as toeskouers van hierdie "dodedans" die dooies nie te verag nie, maar as broeders van die skuldiges tot God te bid dat Hy hulle sal vergewe. Reeds in die aanvangsvers, "Frères humains qui apres nous vivez" ("Brother men, who after us shall stay") impliseer sy versoek dat die afstand tussen veroordeelde en diegene wat hom veroordeel, uitgewis moet word. Dit herinner 'n mens onmiddellik aan Breytenbach se "Brief uit die vreemde aan slagter" (Skryt,1972:26-28) waarin die skeiding tussen gevangene en folteraar geleidelik opgehef word, sodat dit uiteindelik gaan om die twee kante 
van een-en-dieselfde muntstuk, naamlik die mens. (André P. Brink ontleed dit op merkwaardige wyse in Woorde teen die wolke (Coetzee,1980:1-28).)

Weens die inherente paradoks van die dodedans-motief (dood geassosieer met dans), vind die zen-paradoks geinspireerde poësie van Breytenbach 'n natuurlike aansluiting hierby. Op sy beurt transponeer Breytenbach 'n moderne (en Zen-Boeddhistiese) weergawe van die vyftiende-eeuse danse macabre op die lewende dood wat hy in gevangenskap ervaar:

en meet my (wat vasmaak is) aan die ek

daarom omdat ek dood is

veral aan die dood

en noem dit dan die ongedanste dans

want o.a. "die gedagte aan die dood (vas)

is 'n loslit danseres" as ook wat geïntegreer is

kan jou nie opponeer nie.

("Nekra" in ("YK"),1983:43-44.)

Opvallend ook in dié verband is die gedig wat begin met "hy dans dan die droë dans van die dood / dat die stof so staan -" wat in ' $n$ Seisoen in die paradys (1976:207-208), opgeneem is. Die slotverse roep onwillekeurig Villon se gehangdes op wat rondswaai aan hulle galg:

hoor hoe brand die klopslae, stofsak

hoor hoe vreet die pyn aan die tou

hoor

en dans dan, blinde ...

Soos Villon beklemtoon Breytenbach die gedagte dat almal gelyk gestel word deur die dood:

jy, mens - rykman en slaaf, swartnerf en witboer

generaal en kelner, pronk-prins en melaatse, steler en regter

hoer en non, Hitler en Anne Frank, Stahin en Gandhi

en Alexander en Sokrates en Nixon en Van Hoi

en Sondernaam en Piet Paul en Klaas -

beul met bewerige hand

en stuipswart streep aan die galg

wanneer die derms gly -

(Voetskrif, 1976:81), en

(Mors estoient, et corps et ames,

En dampnee perdicion,

Corps pourris et ames en flammes,

De quelconque condicion.)

(Men died, both body and soul the same,

condemned alike to long perdition,

bodies to rot and souls to flame;

this comes to men of all condition)

(Le Testament, vv.801-804).

Breytenbach se volgehoue obsessie met ontbinding en die paradoksale 
gegewe dat dood (ook) lewegewend is in die sin dat die dooies die grond bemes en die insekte voed, sluit benewens die Zen-Boeddhistiese aspek daarvan (Brink,1979:8-9) ook aan by 'n eeue-oue literêre tradisie wat só weerklank vind in Villon se Testament.

Item, mon corps j'ordonne et laisse

a nostre grant mere la terre;

les vers n'y trouveront grant gresse,

Trop luy a fait fain dure guerre.

Or luy soit delivré grant erre:

De terre vint, en terre tourne;

Toute chose, se par trop n'erre,

Voulentiers en son lieu retourne.

(Item: my body I now ordain

To grandmother earth, with her to lie.

But little fat the worms will gain,

For hunger made war on its savagely.

May I leave the earth full speedily.

From earth it came, to the earth will turn.

Unless they wander too far and free,

All things with joy to their place return.)

(Le Testament, vv.841-848).

Beide voorbeelde sluit literêr-histories aan by 'n Bybelse tradisie wat reeds in Genesis 3:18-19 aangetref word: "In die sweet van jou aangesig sal jy brood eet totdat jy terugkeer na die aarde, want daaruit is jy geneem. Want stof is jy, en tot stof sal jy terugkeer".

\section{Stilistiese ooreenkomste}

Opvallend stilistiese ooreenkomste in die werk van Villon en Breytenbach is die gebruik van parodie of pastiche, die uitgebreide gebruik van woordspel en tegnieke van ambivalensie (soos semantiese opeenstapeling wat na die meervoudige interpretasie van 'n woord lei, dubbelsinnige sintaksis, spel met die homonimie van woorde), en verder ook die doelbewuste gebruik van die paradoks as kreatiewe prinsiep. Hierdie tegnieke is natuurlik geensins uniek aan die betrokke twee oeuvres nie, maar dit is opvallend dat die uitgebreide gebruik daarvan wél op dieselfde manier geïnterpreteer kan word.

\subsection{Parodie en pastiche}

Villon se Testament is 'n pastiche, soms parodie, van 'n werklike testament wat 'n persoon voor sy dood opstel om sy besittings aan ander te bemaak. In hierdie baie lang gedig word Villon se familie en kennisse, denkbeeldige figure al dan nie, een na die ander opgenoem, telkens aan die hand van dit wat hy aan elkeen bemaak. Ook in sy vroegste werk, die Lais wat erfnis beteken, word daar gesinspeel op die toon en formulering van 'n regsdokument waardeur die eiendom van 'n afgestorwene aan ander oorgedra word. 
Binne die konteks van die oorkoepelende parodie van beide die Lais en Le Testament kom afsonderlike gevalle van parodie voor, byvoorbeeld van metafore uit die hoofse liefdespoësie. 'n Voorbeeld hiervan is strofe II van die Lais waar Alain Chartrier se "Belle dame sans merci" geparodieer word met:

Et qu'on se tient en sa maison,
pour le frimas, pres du tison,
Me vint ung vouloir de brisier
La tres amoureuse prison
Qui souloit mon cuer debrisier.
(And when we stay indoors for fear
Of frost, and to the fire draw near,
Desire came to me then to take
Leave of Love's prison, harsh yet dear,
Which once did make my poor heart break.)

Nóg voorbeelde van parodie binne die oorkoepelende pastiche is strofes XXXII en XXXI van Le Testament waar denkbeeldige erflatings, of erflatings waarmee uitsluitlik gespot word, aangetref word.

Ook by Breytenbach is die parodie en die pastiche nie altyd maklik van mekaar te onderskei nie, hoewel eersgenoemde seker die meeste voorkom. Vergelyk in hierdie verband sy voorliefde om tradisionele volksliedjies in gesegdes om te dig, soos byvoorbeeld: "Vanaand gaan die poppe wals, / die volkies koring sny -" (Die huis van die dowe,1967:99). Veral in die latere Lewendood (1985) word volksliedjies, sowel as grepe uit die gekanoniseerde Afrikaanse poësie, herhaaldelik geparodieer om 'n kerngegewe van die bundel te vorm.

Suiwer pastiche is onder meer die omdigting van Celliers se "Dis al" (Lewendood,1985:25), die reeds genoemde "Ballade van ontroue bemindes" ("YK"),1983:112-113) en die talryke omdigtings van bekende passasies uit die Bybel soos byvoorbeeld hierdie spel op 1 Korintiërs 13:1 en 13:

want dan bly daar net woede, wanhoop en pyn;
maar die sterkste hiervan is die pyn;
want as jy die pyn nie het nie
word jy 'n klinkende simbaal.

(Die huis van die dowe,1967:79).

\subsection{Woordspel en ambivalensie}

Kenmerkend van albei digters is hul voorliefde vir woordspel, in die besonder, semantiese opeenstapeling by eiename en soortname. Villon verander byvoorbeeld die materiaalhandelaar Marbeuf se naam na Merebeuf (Le Testament v.1046) om te suggereer dat die man 'n skurk is; 'n opperste gemene bees: mere (leier in Middelfrans), en beuf (bees). So ook word die ryk handelaar Nicolas de Louviers se naam na Louvieulx (Le Testament v.1047) verander om die geaardheid van 'n ervare (en daarom geslepe) ou wolf te 
suggereer: Loup (wolf), vieulx (ou, bejaarde). Nóg 'n voorbeeld is seigneur de Grigny (Le Testament, v.1346) waar gesinspeel word op grignos (hy wat sy tande wys) om te verwys na die twisgierige Phillipe Brunel. Aan hóm bemaak Villon die waardelose, geruïneerde houttoring Billy; 'n benaming wat ryk is aan allerlei assosiasies: une bille (wegkruipplek binne 'n hol boomstam); des billes (klein stukkies gebreekte hout soos dié wat oral by die toring rondlê); un billot (houtbalk waaraan iemand vasgebind word om gefolter te word); $d u$ billon (kopermuntstukke van geringe waarde).

Hierdie tegniek van Villon om 'n eienaam of 'n soortnaam semanties so veel as moontlik te laai, herinner onwillekeurig aan die manier waarop Breytenbach soms sy eie naam hanteer, soos "Bullebach", "Braakinpag", "Breitenbog" (Lewendood,1985:129); "Prenten Prentenbach" (Eklips,1983:31) en "Breipen Breytenbach" (Eklips,1983:63), telkens met voor-die-hand-liggende assosiasies en afleidings.

Semantiese opeenstapeling is per slot van sake een van die kenmerkendste aspekte van die Breytenbach-oeuvre. Om 'n paar willekeurige voorbeelde te noem: "skaweduwee" (Lewendood,1985:75) wat binne die betrokke konteks geassosieer word met skaduwee, skaaf (of skawe) en weduwee; die "woerdende oseaan" (("YK"),1983:45), en speling op wordende en woedende; "snig" (("YK"),1983:26) wat onder meer snik, sug en swik suggereer, en ook die bekende geval van die bundeltitel Skryt (skreeu, skrei, kryt, skyt, ry, skrif en $s k r y f$ ), soos aangetoon deur Ten Berge in die voorwoord tot Skryt (1972:61). Verder is sintaktiese dubbelsinnigheid en spel met die homonimie van woorde 'n opvallende aspek van beide digters se woordkuns.

\subsection{Die gebruik van die paradoks}

Soortgelyk aan die kenmerkende paradoksgegewe in die poësie van Breytenbach, is die gebruik van antitese by Villon opvallend en vernuwend in die Middeleeuse poësie, en is dit veral die vulgêre wat met die verhewe gekontrasteer word, byvoorbeeld:

Car en amours mourut martir:

Ce jura il sur son couillon,

Quant de ce monde voult partier.

(For, as love's martyr did he die.

He swore this oath his balls upon,

When from this world he wished to fly.)

(Le Testament, vv.2001-2003)

Hierdie verskynsel moet gesien word binne die vyftiende-eeuse konteks van algemene ontgogeling met verhewe hoofse liefde, wat duidelik na vore kom in die paradoksale wyse waarop Villon die vrou (hetsy minnares, hoer, biologiese moeder en Moeder van God) ervaar. Belangrik egter is dat Villon die growwe, die vulgêre, die skatalogiese gebruik juis in 'n poging om by wyse 
van kontras die skone en die suiwere op te roep, en wend hy die paradoks dus op baie moderne wyse aan as kreatiewe prinsiep. (Ook by Breytenbach word die vulgêre of die skatalogiese gebruik om op paradoksale wyse (ZenBoeddhisties maar ook as 'n soort alchemistiese proses) die suiwer poëtiese op te roep: "om van hondedrolle/sterre te maak", stel hy dit in Lotus,1981:9.)

Benewens die gebruik van die paradoks as kreatiewe beginsel, is die paradoks by Villon ook simptomaties van 'n eksistensiële onsekerheid, oorgawe aan 'n lewenswyse wat geen vertroosting meer vind in die konvensies van die Middeleeue nie (vgl. Martineau-Génieys, 1978:175-187). Vergelyk in hierdie verband sy "Ballade des contre vérités" ("Ballad of paradoxes"):

Il n'est soing que quant on a fain,

ne service que d'ennemy ...

(Only when hungry do we take care,

men are only helped by an enemy ...)

Villon se doelbewuste poging om by wyse van woordspel, dubbelsinnighede en so meer, die interpretasie van sy poësie so polivalent as moontlik te maak, kan toegeskryf word aan sy persoonlike lewensfilosofie wat in 'n neutedop vergestalt word in "Ballade du concours de Blois". In hierdie gedig verskaf Villon 'n uiterste geval van paradoks, deur sy (vir dié tyd) onkonvensionele, moontlik agnostiese (vgl. Martineau-Génieys,1978:184-187) lewensfilosofie op te som in 'n gedig wat hy gebruik as inskrywing vir 'n poësie-wedstryd te Blois, 'n tradisionele instelling van die Middeleeuse Rederykerskamers. Hy gebruik dus doelbewus juis 'n uiters gevestigde en konvensionele instelling as geleentheid om sy onkonvensionele, eksistensiële onsekerheid te verwoord. Behalwe miskien in die geval van Rutebeuf se geskrifte (laat dertiende eeu) kom die Middeleeuse literêre konvensies met voorafbepaalde temas hiermee tot 'n einde, en vind 'n oorgang plaas na 'n nuwe sterk individualistiese digkuns soos wat dit vandag nog in die moderne poësiewêreld beoefen word.

Rien ne m'est seur que la chose incertaine;

Obscur, fors ce qui est tout evident;

Doubte ne fais, fors en chose certaine;

Science tiens a soudain accident;

Je gaigne tout et demeure perdent ..."

(I've nothing sure save in uncertainty,

No darkness save in every plainest thing.

I have no doubts except in certainty.

A sudden accident will knowledge bring.

I always win, yet I lose everything ...)

Hierdie lewenshouding van Villon word direk weerspieël in die polivalente aard van sy digkuns oor die algemeen. In die lig van 'n stelling soos "rien ne m'est seur que la chose incertaine" kan die Villon-oeuvre dus beskou word as 'n doelbewuste spel van parodie, ambivalensie en metamorfose (soos die karnavalverskynsel wat deur Bakhtin (1970:20) omskryf word, waar bestaande hiërargieë omgedraai word en alle taboes verbreek word om met 
opset die relatiwiteit van alle waarheid en gesag te beklemtoon). "Le texte littéraire devient le lieu de la décomposition du réel, et surtout de sa métamorphose" (Dufournet,1987:2635). Net soos wat die individu sy lewe in hierdie oorgangsfase van Middeleeue na Renaissance as gefragmenteerd en onseker ervaar, net so is die betekenis van die ambivalente teks oop vir verskillende interpretasies. Villon bied doelbewus die teks aan as ruimte waar die waarheid of die werklikheid ontbind kan word deur die voortdurende verskuiwing van moontlike betekenisse - die dekonstruksie van 'n Derrida dus ver vooruit! 'n Mens kan dié inherente eienskap van die poësie van Villon sien as sy reaksie teen 'n onseker en moeilike wêreld, waar die Middeleeuse ideale van ridderskap, hoofse liefde en lojaliteit besig was om te verbrokkel en nie meer die sekuriteit en vertroosting van vroeër kon bied nie. Onder die dekmantel van spottende ironie en bitter humor weerspieël sy poësie die angs en onsekerheid van die einde van 'n era, in hierdie geval die oorgang van die Middeleeuse kultuur met sy bekende kerklike dogmas na die drif en vitaliteit van die nog onbekende Renaissance.

Benewens al die ander parallelle kenmerke in die werk van die twee digters, is die raakpunt met Breytenbach in hierdie verband betekenisvol. Nie alleen maak Breytenbach van dieselfde tegnieke van ambivalensie gebruik nie (byvoorbeeld verwarrende sintaksis, semantiese opeenstapeling en spel met die homonimie van woorde), maar leen veral sy tronkpoësie die teks by uitstek tot dekonstruksie. (Vergelyk in hierdie verband André P. Brink (1984:18) se kommentaar oor (" $Y K^{\prime \prime)}$ )) Die feit dat dit so dikwels in sy digkuns juis nie gaan oor konkrete dinge wat benoem word nie, en dat die polivalente aard van die teks vir hom simptomaties is van die mens se onvermoë om 'n sentrum van betekenis vir goed "vas te vang" of te bepaal, is, soos in die geval van Villon, 'n teken van die wyse waarop hy sy wêreld ervaar. ("Illusies breek altyd weer pêrelmoeder oop" stel hy dit in ("YK"),1983:43-44.)

Die verbrokkeling van die Afrikanerdom oor die algemeen, en meer in die besonder Breytenbach se verwerping van waardes waarmee hy groot geword het, vind uiting en weerspieëling in die polivalente aard en inhoud van sy woordkuns sowel as in sy doelbewuste parodiëring van die gekanoniseerde poësie. Meer nog, soos in die geval van Villon, is dit wêreldwyd simptomaties van die verlies wat deur die digter as "barometer" van 'n gemeenskap in enige historiese of kulturele oorgangsfase ervaar word. In Breytenbach se geval is sy woordkuns miskien simptomaties van die oorgang van die apokaliptiese twintigste eeu, met sy onheilspellende ontwikkelinge op die gebied van atoomkrag, na die nog onbekende een-en-twintigste eeu, maar ook binne die konteks van 'n Suid-Afrika waaraan hy steeds verknog bly, is dit simptomaties van 'n oorgang na 'n tyd waar nuwe oplossings en antwoorde gevind moet word, altyd met die wete dat ook dít weer plek sal moet maak vir vernuwing.

In albei gevalle lê die waarde van beide digters se werk juis daarin dat dit wyer strek as net hul persoonlike ervaring: dit is betrokkenheidskuns wat 
spreek namens 'n hele gemeenskap wat saam met die digter pynlik bewus is van 'n veranderde wêreld; van die wegbreek uit geykte tradisies.

\section{Slotopmerking}

Die parallel tussen Villon en Breytenbach is dus nie bloot anekdoties nie, maar dien as illustrasie van die feit dat die poësie van Breytenbach oor die algemeen bestaansreg geniet binne 'n groter konteks as nét die aktuele, nét die Suid-Afrika van hier en nou. Die Villon- sowel as die Breytenbach-teks konstitueer 'n spesifieke diskoers van digters wat as enkelinge, maar nogtans namens ' $n$ anonieme groep enersdenkendes hul ervaring van 'n veranderende wêreld verwoord. Gesien die kragtoer van Breytenbach se meer resente poësie is die implikasie hiervan dat die Breytenbach-oeuvre daarin slaag om uit te kring van die egosentriese en die mimetiese na die universele en die semiotiese, en sodoende aansluiting vind by 'n wêreldtradisie in die letterkunde waar die kerngegewe van die gedig hom afspeel in ' $n$ heel ander dimensie as wat op die eerste vlak van betekenis vermoed word.

\section{Bibliografie}

Bakhtin, M. 1970. L'oeuvre de François Rabelais et la culture populaire au Moyen Age et sous la Renaissance. Parys: Gallimard.

Breytenbach, B. 1964. Die ysterkoei moet sweet. Johannesburg: Afrikaanse Pers-boekhandel.

Breytenbach, B. 1967. Die huis van die dowe. Kaapstad: Human en Rousseau.

Breytenbach, B. 1972. Skryt. Om 'n sinkende skip blou te verf. Amsterdam: Meulenhoff.

Breytenbach, B. 1976. Voetskrif. Johannesburg: Perskor.

Breytenbach, B. 1981a. Kouevuur. Johannesburg: Taurus.

Breytenbach, B. 1981b. Lotus. Johannesburg: Taurus.

Breytenbach, B. 1983. ("YK"). Johannesburg: Taurus.

Breytenbach, B. 1984. Buffalo Bill. Johannesburg: Taurus.

Breytenbach, B. 1985. Lewendood. Johannesburg: Taurus.

Breytenbach, B. 1986. 'n Seisoen in die paradys. Johannesburg: Perskor.

Brink, A.P. 1979. Die poësie van Breyten Breytenbach. Pretoria: Academica.

Brink, A.P. 1984. Is dit Breyten en Afrikaans se grootste dié? Rapport, Jan. 29/:18.

Brink, A.P. 1984. Meer mense sal dié Breyten verstaan. Rapport, Feb. 5/:15.

Charpier, J. 1958. François Villon. Parys: Editions Pierre Seghers.

Coetzee, A.J. (red.). 1980. Woorde teen die wolke. Vir Breyten. Johannesburg: Taurus.

Dufournet, J. 1980. Nouvelles recherches sur Villon. Parys: Editions Honoré Champion.

Dufournet, J. 1987. François Villon. Dictionnaire des littératures de langue française. Parys: Bordas.

Friedman, L. 1957. The ubi sunt, the regrets and effictio. Modern Language notes. LXXII:499505, Nov.

Gilson, E. 1932. Les idées et les lettres. Parys: Vrin.

Hutcheon, Linda. 1981. Ironie, satire, parodie. Poétique. Revue de thérie et d'analyse litteraires, 46:140-155. April. Parys: Seuil.

Jung, C.J. 1971. Les racines de la conscience. Parys: Editions Buchet/Chastel.

Krige, U. 1950. Vir die luit en die kitaar. Johannesburg: Afrikaanse Pers-boekhandel.

La Marche, O. de. 1901. Le parement et le triomphe des dames d'honneur, 1510. Parys: Edition Kalbfleisch.

Le Gentil, P. 1967. Villon. Connaissance des lettres. Parys: Hatier.

Michel, P. 1972. Villon. Poésies complètes. Parys: Librairie générale française. 
Roy, B. 1979. Amour, fortune et mort - La danse des trois aveugles In: Sutton, C. (ed.). Le sentiment de la mort au moyen âge. Québec: Les editions univers inc. p.119-138.

Saklatvala, B. 1968. Complete Poems of François Villon. London: Dent.

Schnürer, G. 1933-35. L'église et la civilisation au Moyen Age. Deel II. Parys: Payot.

Sutton, C. (red.). 1979. Le sentiment de la mort au moyen áge. Québec: Les éditions univers inc. Van Altena, E. 1965. François Villon. Verzamelde gedichten. Amsterdam: Van Ditmar.

Van Dis, A. 1974. Tien boeken van Breyten Breytenbach. De Vlaamse Gids, 58(6):40-52.

Universiteit van Durban-Westville 